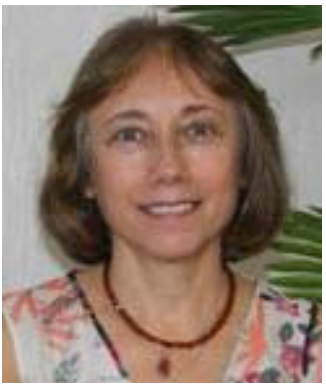

\title{
A caminho da excelência
}

$\mathrm{O}$ atual volume inicia um novo ciclo da SMAD, pois atualmente a revista já adquiriu a "maturidade" suficiente para lançar três edições anuais. Essa iniciativa constitui uma vitória de todos os pesquisadores em saúde mental/ álcool e drogas, que desde o início tem acreditado no potencial da revista, prestigiando-a com o envio de suas experiências acadêmico científicas. A expectativa é de que persistam nessa crença e mantenham seu entusiasmo em relação à SMAD.

Graças ao apoio da Secretaria Nacional de Políticas Sobre Drogas-SENAD, haverá recursos para implementar inovações necessárias para modernizar e situar a revista em níveis mais elevados de classificação. Investimentos serão feitos no sistema de submissão, na sua página, e na sua internacionalização.

Assim, um futuro promissor se delineia para a SMAD. Certamente, o que se mostrou positivo será mantido, como por exemplo, a diversidade nas publicações, fato contatado no seu acervo (que de agora em diante pode ser acessado também no BEDenf ), mostrando que a revista não tem problemas de endogenia, um dos critérios valorizados pelas instâncias avaliadoras de revistas científicas.

Neste número, pesquisadores de outras regiões do Brasil e cidades do Estado de São Paulo, convidam à leitura e estimulam a reflexão sobre conhecimentos bastante distintos e aplicáveis tanto ao cuidado quanto à prevenção de agravos à saúde; focalizam-se no aspecto comorbidades em grupos específicos e de risco. Também são abordados a ocorrência do consumo de álcool, religiosidade como fator protetor do uso de substâncias psicoativas, os significados das imagens aversivas dos maços de cigarros e por fim, um artigo de revisão fazendo uma retrospectiva das atitudes e conhecimentos de profissionais de saúde frente ao álcool, alcoolismo e alcoolista. Sem dúvida, as pesquisas registradas neste número são bastante instigadoras.

Boa leitura!

\section{Margarita Antonia Villar Luis}

Editora da SMAD, Revista Eletrônica Saúde Mental Álcool e Drogas e Professor Titular da Escola de Enfermagem de Ribeirão Preto, Universidade de São Paulo, Centro Colaborador da OMS para o desenvolvimento da pesquisa em enfermagem, Brasil, e-mail: margarit@eerp.usp.br 